\title{
Hasil Kemampuan Empati Anak Usia Dini Melalui Metode Bercerita Menggunakan Media E-Bigbook
}

\author{
Komang Sukma Pertiwi Dialektika \\ Program Studi Pendidikan Guru Sekolah Dasar, Universitas Pendidikan Ganesha \\ omang.sukma@gmail.com
}

\author{
A R T I C L E I N F O \\ Article history: \\ 1 Januari 2020 Received in \\ revised form \\ 30 Mei 2020 \\ Accepted 30 Juni 2020 \\ Available online \\ 15 Juli 2020 \\ Kata Kunci: \\ Kemampuan Empati, Bercerita \\ Media e-bigbook \\ Keywords: \\ empaty ability, storytelling, $e$ - \\ bigbook media
}

\begin{abstract}
ABSTRAK
Kemampuan empati merupakan kemampuan yang dimiliki setiap individu untuk ikut merasakan yang orang lain rasakan atau mampu memposisikan diri seperti yang sedang orang lain alami. Mengingat kemampuan empati yang diperlihatkan masih tergolong belum berkembang secara maksimal, akan tetapi guru belum memberikan stimulus melalui media pembelajaran yang efektif. Maka dari itu pelaksanaan dalam penelitian ini dilaksanakan untuk mengetahui pengaruh metode bercerita menggunakan media e-bigbook terhadap kemampuan empati anak kelompok B. Dalam penelitian ini kemampuan empati menjadi bahan
\end{abstract} yang akan diteliti lebih dalam. Eksperimen semu merupakan jenis dalam penelitian ini dengan menggunakan Nonequivalent Control Group Design. Populasi pada penelitian ini berjumlah 60 anak dengan sampel yang ditentukan secara random. Sampel pada penelitian ini terdiri dari kelompok B1 berjumlah 20 anak sebagai kelompok eksperimen dan kelompok B2 berjumlah 20 anak sebagai kelompok kontrol TK Inklusi Garuda Bilingual School. Pada penelitian ini data dikumpulkan menggunakan teknik observasi, kemudian dianalisis dengan uji-t. Hasil analisis data, $\mathrm{t}_{\text {hitung }}=6,80$, taraf signifikansi $5 \%, \mathrm{dk}=38$ diperoleh $\mathrm{t}_{\text {tabel }}=2,021$ sehingga $\mathrm{t}_{\text {hitung }}=$ $6,80>t_{\text {tabel }}$ 2,021. Berdasarkan kriteria pengujian, maka $\mathrm{H}_{0}$ ditolak dan $\mathrm{H}_{\mathrm{a}}$ diterima. Jadi, penggunaan metode bercerita menggunakan media e-bigbook berdampak terhadap kemampuan empati anak. Penelitian ini dapat membantu guru sebagai inovasi dalam media pembelajaran.

\section{ABSTRACT}

The ability of empathy is the ability that each individual has to share in how others feel or are able to position themselves as others are experiencing. Considering that the empathy ability shown is still relatively underdeveloped, the teacher has not provided stimulus through effective learning media. Therefore, the implementation in this study was conducted to determine the effect of the method of storytelling using e-bigbook media on the empathy ability of group B children. Quasi-experimental is the type in this study using Nonequivalent Control Group Design. The population in this study amounted to 60 children with a randomly determined sample. The sample in this study consisted of B1 group with 20 children as the experimental group and B2 group with 20 children as the Garuda Bilingual School Inclusion Kindergarten control group. In this study data were collected using observation techniques, then analyzed by t-test. The results of data analysis, tcount $=6.80$, significance level of $5 \%, \mathrm{dk}=38$ obtained ttable $=2.021$ so tcount $=6.80>$ ttable 2.021. Based on testing criteria, H0 is rejected and $\mathrm{Ha}$ is accepted. So, the use of storytelling using e-bigbook media has an impact on children's empathy abilities. This research can help teachers as innovations in learning media. 


\section{PENDAHULUAN}

Pendidikan anak usia dini (Fudyartanta, 2016), diperuntukan untuk anak sejak lahir hingga usia 6 tahun yang bertujuan untuk mengembangkan kepribadian anak. Anak merupakan individu yang sudah dibekali dengan potensi yakni secara fisik, psiko, bahsa dan juga kognitif yang dibawa ejak lahir (Masdudi, 2015). Pada fase anak usia dini (Khairi, 2018), merupakan fasa anak mengalami pertumbuhan dan perkembangan yang pesat sehingga pada usia ini adalah masa pembentukan karakter bagi anak.

Program pendidikan pada umumnya hanya menerapkan program regular dimasingmasing sekolah. (Juita, 2012) menjelskan bahwa program regular adalah program pendidikan yang menampung anak dengan perkembangan dan pertumbuhan yang sesuai dengan usianya disekolah. Seiring dengan berjalannya waktu, kepedulian masyarakat terhadap anak berkebutuhan khusus semakin meningkat. Maka dibentuklah program pendidikan yang menjangkau anak dengan kebutuhan khusus dan anak non ABK yang disebut dengan pendidikan inklusi. Pendidikan inklusi (Heldanita, 2018) merupakan pendidikan yang dapat menggabungkan anak dengan kebutuhan khusus dan anak non ABK pada sistem pembelajaran yang sama didalam satu kelas. Ini berarti bahwa program pendidikan inklusi merupakan wadah bagi siswa dengan keistimewaannya dapat belajar dan mengembangkan kemampuannya bersama dengan siswa non ABK.

Pelayanan yang diberikan pada sekolah yang mengadakan program inklusi (K. M. P. Dewi et al., 2018) akan memenuhi kebutuhan setiap siswanya baik yang berkebutuhan khusus dan yang non ABK mulai dari, sarana-prasarana, kurikulum, sistem pembelajaran hingga sistem penilaiannya agar memiliki kesamaan. (Paramita et al., 2018)berpendapat bahwa dalam hal pendidikan, negara memberikan jaminan kepada seluruh anak didik di Indonesia tanpa terkecuali, untuk memperoleh pendidikan yang setara dan sesuai dengan apa yng diperlukan oleh anak tersebut. Sehingga layanan pendidikan anak usia dini dengan kebutuhan khusus perlu wajib diselenggarakan dan dijamin keberlangsungannya oleh Negara.

Aspek perkembangan yang terdapat pada PAUD regular maupun PAUD inklusi (Fauziddin \& Mufarizuddin, 2018), mencakup aspek nilai agama dan moral, kognitif, bahsa, fisik motorik, sosial emosional dan seni. Salah satu aspek sosial emosional yang dapat dikembangkan yakni kemampuan empati pada anak. (Susanto, 2015) menjelaskan bahwa empati merupakan perasaan seseorang yang ikut merasakan perasaan orang lain lalu kemudian mengkomunikasikannya dengan berbagai cara sehingga menunjukkan bahwa ia tengah ikut merasakan perasaan yang dialami orang lain.

Empati memiliki arti ikut merasakan atau dengan kata lain disebut empatheia yang biasanya digunakan oleh para teoritikus estetika untuk pengalaman subjektif orang lain (Silfiasari, 2017). Empati (Silfiasari, 2017), merupakan kegiatan untuk memahami perasaan emosional yang dihadapi orang lain. Sesuai dengan penjelasan yang dipaparkan, empati merupakan cara anak untuk belajar bagaimana menempatkan diri pada keadaan orang lain secara perlahan. Tingkat kecapan anak dapat berpengruh pada empatinya, semakin tinggi kecapakan sosial anak maka akan lebih mudah anak membentuk dan membangun hubungan dengan orang lain (Safitri et al., 2018).

Dalam kenyataannya masih banyak anak yang memiliki rasa empati yang belum berkembang secara maksimal. Rasa egosentri tinggi yang dimiliki anak dapat menimbulkan pada anak rasa kurangnya bertoleransi, rasa kasih sayang dan peduli dengan temannya, Selain itu juga kurangnya penanaman empati sejak dini maka terjadi kasus-kasus 
perundungan, kejahatan kekerasan, dan perilaku agresif (N. P. D. S. Dewi et al., 2019). Kasus tersebut masih sering terjadi di sekolah regular maupun dalam sekolah inklusi. Menurut (Faizah et al., 2017) menjelaskan bahwa siswa regular masih belum bisa memahami bagaimana perasaan siswa berkebutuhan khusus ketika tidak memiliki teman pada saat waktu luang. Salah satu contoh kasus perundungan untuk anak berkebutuhan khusus terjadi di kota padang (Sakinah \& Marlina, 2018), anak berkebutuhn khusus sering dianggap menjadi penghambat dalam proses pembelajaran karena gaya belajarnya tidak seperti anak pada umumnya. Beberapa faktor yang menjadi penyebab anak berkebutuhan khusus mengalami kasus perundungan (Sufriani \& Sari, 2017) diantaranya: faktor individu, faktor keluarga dan teman sebaya. Kemudian dalam permasalah perundungan ini serin kurang mendapat perhatian dikarenakan para korban lebih memilih untuk diam diakibatkan korban malu dan dianam oleh pelaku perundungan. Penelitian yang dilakukan (Listika \& Wati, 2018), menjelaskan terdapat kasus bullying yang dilakukan oleh siswa normal terhadap siswa ABK yaitu: perilaku bullying fisik sebesar 27,05\%, bullying verbal $46,87 \%$ serta bullying psikologis sebesar 32,49\%.

Anak lebih senang bermain sendiri, anak belum dapat membagi muniman atau makanan dengan temannya, anak belum terbiasa memberi atau menerima maaf ketika melakukan kesalahan, merupakan bukti bahwa kemampuan empati anak belum berkembang secara maksimal dan anak dapat menimbulkan keributan saat pembelajaran karena anak tidak mengikutsertakan temannya dalam kegiatan pembelajaran. Dalam penelitian yang dilakukan oleh (Hasanah \& Nurhamida, 2016) salah satu kasus perundungan yang terjadi pada anak berkebutuhan khusus dikelas inklusi daerah Kalimantan selatan. Pada kasus tersebut memperlihatkan bahwa anak-anak regular dikelas inklusi mencemooh anak berkebutuhan khusus. Dengan perbuatan yang tidak sepantasnya baik dilakukan itu, anak-anak regular pada kelas inklusi menjadi memiliki rasa empati yang belum maksimal terhadap temannya yang berkebutuhan khusus.

Pada hari senin tanggal 9 Desember 2019 telah melaksanakan observasi di TK Garuda Billingual School, dimana sekolah ini merupakan sekolah penerima ank dengan kebutuhan khususnya dalam sistem pembelajarannya yang disebut dengan sekolah inklusi atau TK Inklusi. Didapati bahwa kemampuan empati anak kelompok B masih belum berkembng dengan baik berdasarkan dari hasil wawancara dengan pihak guru. Perilaku ini ditunjukkan dari sikap anak yang tidak mau menjalin pertemanan dengan anak berkebutuhan khusus serta anak belum mampu berbagi dengan anak berkebutuhan khusus. Hal ini disebabkan karena kurangnya stimulasi pemahaman tentang rasa empati yang diberikan bagi anak. Kemudian dari beberapa metode yang digunakan guru seperti metode ceramah, metode bercerita dan metode lainnya dalam penyampaiannya tentang empati masih kurang diimbangin dengan contoh langsung yang dapat dilihat oleh anak serta menggunakan media yang kurang berinovasi bagi anak dan media yang kurang menarik sehingga bersifat monoton.

Dari kasus yang telah banyak terjadi didunia pendidikan, guru harusnya memberi pemahaman kepada anak regular untuk menerima keberadan dari temannya yang berkebutuhan khusus. Maka diperlukan metode yang mampu mengembangkan kemampuan empati anak seperti salah satunya metode bercerita. Mengembangkan nilai moral dan agama serta sosial emosioanal (Anggraeni et al., 2019) dapat melalui kegiatan bercerita dikarenakan dengan bercerita anak dapat menjadikan pesan yang disampaikan guru dalam cerita sebagai pelajaran dalam kehidupan. Tujuan digunakannya metode 
bercerita yaitu, agar guru lebih dimudahkan penyampaian pesan dan pembelajarannya. Sehingga anak dapat lebih mudah memahami maksud guru karena sudah diberikan contoh langsung.

Bercerita memiliki posisi pertama yang umum disukai oleh anak. Kegiatan bercerita (Prihanjani et al., 2016), merujuk pada kegiatan penyampaikan pesan yang dilakukan secara lisan dengan alat atau tanpa alat. Bercerita menduduki posisi pertama untuk membentuk etika pada anak (Pratama \& Simaremare, 2016), penyampaian yang dilakukan dengan cara yang menyenangkan dapat mempermudah anak memahami dan mengekspresikan imajinasi yang dirasakan. Tujuan dari penerapan metode bercerita (Paramita et al., 2018) menunjukkan agar anak mampu mengdengarkan dengan baik apa yang disampaikan oleh orang lain.

(K. M. P. Dewi et al., 2018) menjelaskan bahwa dalam memperkenalkan dan mengajarkan empati kepada anak berkebutuhan khusus, guru lebih mengadaptasi ceritacerita yang mudah dipahami dan dijumpai oleh anak. Dalam penyampaian cerita kepada anak guru lebih mengikuti situasi didalam kelas agar anak lebih memperhatikan cerita yang disampaikan. Bercerita menjadi pilihan orang tua yang sering digunkanan dalam mendidik anaknya untuk menanamkan dan mengajarkan nilai-nilai luhur sejak dini (Putri, 2017). Menurut (Ambarani et al., 2015) metode bercerita dapat diterapkan pada anak usia dini, dikarenakan anak suka mendengar cerita dan situasi seperti ini baik dilaksanakan untuk menjalani kegiatan program.

Media yang digunakan oleh guru untuk melaksanakan pembelajaran salah satunya dapat melalui media $e$-book. Perbedaan media e-book dengan buku (Widalisma \& Lestari, 2017) pada umumnya terletak pada isinya, yakni bila buku menggunakan kertas yang berisikan tulisan dan gambar maka media $e$-book berisi informasi dan teks secara digital. Karakteristik yang dimiliki e-book cukup khas (Rahmawati, 2019), dengan gambar yang dipenuhi warna, kata yang digunakan dapat diulang dan memiliki pola kalimat yang sederhna. Dengan penyampaian pesan yang dapat dilakukan berulang anak lebih mudah untuk menangkap pesan yang dimaksud dalam cerita tersebut. Kemudian penggunaan pola teks yang sedrhana dapat memudahkan anak untuk memahami isi pesan pada cerita tersebut. Dalam penjelasan (Sulaiman, 2017) buku dengan gambar, tulisan serta ukuran dari buku itu sendiri berukuran besar disebut dengan bigbook. Bigbook memiliki karakteristik yang berbeda yakin, dibesarkan ukuran baik teks maupun gambarnya, sehingga dapat memunculkan kegiatan aktif antara guru dan murid.

Dari kelebihan yang dimiliki metode bercerita dalam meningkatkan kemampuan empati anak, dalam penelitian ini peneliti menerapkan inovasi baru yaitu melakukan kegiatan bercerita menggunakan media e-bigbook. Media e-bigbook merupakan media buku yang dirancangan dalam bentuk elektronik dengan ukuran tulisan dan gambarnya yang besar sehingga tampilan yang disuguhkan kepada anak didik lebih jelas dan mampu menarik pusat perhatian anak. Dalam kegiatan bercerita menggunakan media e-bigbook diselipkan pesan moral untuk menerima anak dengan berkebutuhan khusus, sehingga anak lebih mudah untuk memahami pesan dari cerita yang disampaiakan dan proses pembelajaran lebih bermanfaat. Media e-bigbook memiliki perbedaan dengan media bigbook dan media e-book, perbedaannya yaitu tampilan dari media e-bigbook diranangan seperti media bigbook yang pertayangannya memuat satu halaman dengan ukuran yang lebih besar dari ukuran buku pada umumnya namun pada e-bigbook penyampaiannya 
dilakukan dengan kelengkapakan proyektor atau layar yang besar dan efektif untuk pembelajaran dikelas.

Penelitian ini bertujuan untuk dapat mengetahui pengaruh bercerita menggunakan media e-bogbook terhadap kemampuan anak kelompok b di tk inklusi garuda billingual school tahun ajaran 2019/2020. Secara umum hasil penelitian yang dilakukan dapat bermanfaat di sekolah khususnya jenjang TK, sehingga dapat memperluas pengetahuan tentang model pembelajaran untuk meningkatkan perkembangan dan pertumbuhan anak.

Berdasarkan uraian yang telah dipaparkan, metode bercerita yang digunakan oleh guru memerlukan media yang diperbarui. Oleh karena itu untuk membuktikan adanya pengaruh dari metode bercerita yang menggunakan media e-bigbook terhadap perilaku empati dari anak kelompok B, pada kesempatan ini perlu dirancang sebuah penelitian yang berjudul "Pengaruh Metode Bercerita Menggunakan Media e-bigbook Terhadap Kemampuan Empati Anak Kelompok B di TK Inklusi Garuda Billingual School Tahun Ajaran 2019/2020". Agar dengan adanya penelitian ini dapat meningkatkan kemampuan empati anak.

\section{METODE}

Penelitian ini dilaksanakan di TK Inklusi Garuda Billingual School . Waktu penelitian dilakukan sejak mulai dari Desember 2019 sampai Maret 2020. Eksperimen semu (quasi eksperimen) merupakan pendekatan dalam penelitian ini dengan jenis penis penelitian kuantitaif. Desain dalam penelitian ini menggunakan "Nonequivalent Control Group Design". Dengan menentukan kelompok kontrol dan kelompok eksperimen dilakukan secara acak pada kelas yang ada.

Terdapat tiga tahap dalam penelitian ini yakni: tahap persiapan meliputi, Melakukan observasi awal, Pengambilan sampel penelitian, Menyusun Rencana Program Pembelajaran Harian (RPPH), Membuat rancangan penelitian atau instrument penelitian, Mendiskusikan instrument penelitian. Melaksanakan uji coba instrument. Tahap pelaksanaan meliputi, Melaksanakan penelitian dengan memberikan treatment, Memberikan post-test. Tahap akhir meliputi, Melakukan analisis data hasil penelitian, Melaksanakan analisis data untuk menguji hipotesis.

Langkah awal yang dilaksanakan dalam penelitian ini adalah menentukan populasi untuk menentukan subjek penelitian. Menurut (Sugiyono, 2017) menjelaskan subjek yang dapat diukur dan merupakan unit penelitian yang dapat diambil kesimpulannya adalah populasi. Populasi pada penelitian ini meliputi seluruh anak kelompok B TK Inlusi Garuda Billingual School yaitu berjumlah 60 anak. Teknik cluster random sampling merupakan cara pengambilan sampel pada penelitian ini. Untuk menentukan kelompok eksperimen dan kelompok control menggunakan sistem pengundian. Kelompok eksperimen adalah kelompok B1 berjumlah 20 anak, sedangkan adalah kelompok B2 berjumlah 20 anak.

Data kemampuan empati adlah data yang dikumpulkan dalam penelitian ini pada anak kelompok B TK Inklusi Garuda Billingual School Tahun Ajaran 2019/2020. Metode non test digunakan dalam pengumpulan data. Metode yang digunakan adalah metode non test yakni melalui observasi. (Agung, 2014) menyatakan bahwa observasi merupakan salah satu cara untuk memperoleh hasil penilaian dengan cara melakukan pengamatan secara sistematis. Komponen yang diamati pada saat penelitian diantaranya: kemampuan anak dalam melibatkan anak berkebutuhan khusus dalam kegiatan belajar atau bermain, mampu salng berbagi makanan atau minuman dan mampu membantu anak berebutuhan khusus 
yang mengalami kesulitan. Dalam penelitian ini, untuk menguji instrumen perilaku empati sebelumnya dilakukan uji validitas isi. Uji validitas isi bertujuan agar instrument dalam suatu variabel memiliki ketepatan dengan yang akan diukur. Hasil validitas isi didapat dari penilaian yang dilakukan oleh penguji (judgement expert) yaitu dosen atau orang yang memiliki spesifikasi dalam bidang perkembangan sosial emosional khususnya perilaku empati pada anak usia dini. Hasil dari pengujian instrument menggunsksn penilaian dengan rentang skor 1 sampai 4. Dimana nilai skor 1 berisikan anak tidak peduli dengan teman yang berkebutuhan khusus yang mengalami kesulitan, nilai skor 2 berisikan anak hanya diam melihat teman yang berkebutuhan khusus mengalami kesulitan, nilai skor 3 berisikan nak mau membantu teman yang berkebutuhan khusus dengan arahan dari guru dan nilai skor 4 anak mampu membantu teman yang berkebutuhan khusus tanpa arahan dari guru.

Teknik yang digunakan untuk menganalisis data yang didapat memlalui teknik analisis deskriptis. Kegiatan yang termasuk analisis statistik deskriptif diantaranya adalah menentukan distribusi frekuensi, nilai rerata (mean), standar deviasi dan varians. Analisis data yang dilakukan pada penenlitian ini adalah data hasil dari kemampuan empati anak dan pembelajaran konvensional pada anak kelompok B TK Inklusi Garuda Billingual School. Setelah diberikan treatment sebanyak 6 kali, di akhir tahap eksperimen anak diberikan posttest untuk memperoleh kemampuan empati. Metode analisis data yang digunakan untuk menguji hipotesis menggunakan uji-t, dengan langkah awal melakukan uji prasayat yang meliputi: uji normalitas sebaran data dan uji homogenitas varians.

\section{HASIL DAN PEMBAHASAN}

\section{HASIL}

Data hasil kemampuan empati anak adalah data yang dianalaisis pada penelitian ini dan pembelajaran konvensional pada anak kelompok B TK Inklusi Garuda Billingual School. Data pada penelitian ini dijelaskan menjadi dua yaitu, pertama: kemampuan empati pada anak kelompok B yang dibelajarkan melalui bercerita menggunakan media e-big book dan kedua : kemampuan empati pada anak kelompok B yang dibelajarkan melalui pembelajaran konvensional. Setelah diberikan treatment sebanyak 6 kali, di akhir tahap eksperimen anak diberikan posttest untuk memperoleh kemampuan empati.

Adapun rekapitulasi hasil deskripsi data dapat dilihat pada tabel yang disajikan berikut ini.

Tabel 1. Tabel Deskripsi Kemampuan Emati Kelompok Eksperimen Dan Kontrol

\begin{tabular}{ccc}
\hline Hasil Analisis & Kelompok Eksperimen & Kelompok Kontrol \\
\hline Rata-rata & 89,38 & 72,71 \\
Standar deviasi & 4,16 & 4,38 \\
Varians & 17,32 & 16,14 \\
Nilai maksimum & 95,83 & 79,17 \\
Nilai minimum & 83,33 & 66,67 \\
\hline
\end{tabular}

Rata-rata (mean) yang diperoleh dari sebaran data, sebesar 89,38. Standar deviasi pada kelompok eksperimen 4,16 dan variansnya 17,32. Dari paparan data kemampuan empati pada anak kelompok kontrol dengan nilai tertinggi 79,17 dan nilai terendah 66,67. Dari sebaran data tersebut diperoleh rata-rata (mean) sebesar 72,71, standar deviasi pada kelompok kontrol 4,38 dan variansnya 16,14 
Tabel 2. Rekapitulasi Hasil Uji Normalitas Sampel Penelitian

\begin{tabular}{llcccc}
\hline No & Kelompok Sampel & Total Sampel & $\mathrm{X}_{\text {hitung }}^{2}$ & $\mathrm{X}_{\text {tabel }}^{2}$ & Kesimpulan \\
\hline 1. & $\begin{array}{l}\text { Kelompok } \\
\text { Eksperimen }\end{array}$ & 20 & 1,6 & 11,07 & $\begin{array}{c}\text { Berdistribusi } \\
\text { Normal } \\
\text { 2. }\end{array}$ \\
$\begin{array}{l}\text { Kelompok } \\
\text { Kontrol }\end{array}$ & 20 & 2,58 & 11,07 & $\begin{array}{c}\text { Berdistribusi } \\
\text { Normal }\end{array}$ \\
\hline
\end{tabular}

Hasil perhitungan uji normalitas pada kelompok eksperimen, Chi kuadrat hitung sebesar $\left(X^{2}\right.$ hitung $\left.=1,6\right)$ dibandingkan dengan Chi kuadrat table sebesar $\left(X_{\text {tabel }}^{2}=11,07\right)$. Hal ini menunjukkan bahwa $\mathrm{X}_{\text {hitung }}<\mathrm{X}_{\text {tabe }}$ berarti data kemampuan empati berdistribusi normal. Berdasarkan perhitungan hasil uji normalitas kelompok kontrol , diperoleh Chi kuadrat hitung $\left(\mathrm{X}^{2}\right.$ hitung $\left.=2,58\right)$ kemudian nilai dibandingkan dengan Chi kuadrat table $\left(\mathrm{X}_{\text {tabel }}^{2}=11,07\right)$. Hal ini menunjukkan bahwa $\mathrm{X}_{\text {hitung }}<\mathrm{X}_{\text {tabe }}$ berarti data kemampuan empati berdistribusi normal.

Tabel 3. Uji Homogenitas Varians

\begin{tabular}{ccccccc}
\hline Sampel & Mean & SD & Varians & $\mathrm{F}_{\text {hitung }}$ & $\mathrm{F}_{\text {tabel }}$ & Kesimpulan \\
\hline $\begin{array}{c}\text { Kelompok } \\
\text { Eksperimen }\end{array}$ & 89,38 & 4,16 & 17,32 & & 2,15 & Homogen \\
$\begin{array}{c}\text { Kelompok } \\
\text { Kontrol }\end{array}$ & 72,71 & 4,38 & 19,14 & & & \\
\hline
\end{tabular}

Berdasarkan analisis pada tabel 4, diperoleh $\mathrm{F}_{\text {hitung }}=1,10$ sedangkan $\mathrm{F}_{\text {tabel }}$ pada taraf signifikan 5\% dengan derajak kebebasan (dk pembilang $20-1=19$ dan $\mathrm{dk}$ penyebut $20-$ $1=19$ ) adalah 2,15, sehingga $F_{\text {hitung }}<F_{\text {tabel }}$ sehingga data kedua kelompok memiliki varians yang homogen.

Tabel 4. Hasil Rekapitulasi uji-t Kelompok Sampel Penelitian

\begin{tabular}{cccccccc}
\hline No & Sampel & $\mathrm{N}$ & $\mathrm{Dk}$ & Mean & $\mathrm{t}_{\text {hitung }}$ & $\mathrm{t}_{\text {tabel }}$ & Kesimpulan \\
\hline 1. & Kelompok & 20 & & 89,38 & & & \\
& $\begin{array}{c}\text { Eksperimen } \\
\text { 2. }\end{array}$ & & & & & & \\
& $\begin{array}{c}\text { Kelompok } \\
\text { Kontrol }\end{array}$ & 20 & 38 & 72,71 & 6,80 & 2,021 & $\mathrm{H}_{0}$ ditolak \\
\hline
\end{tabular}

Berdasarkan hasil perhitungan uji-t pada tabel 5, diperoleh $\mathrm{t}_{\text {hitung }}=6,80$. Pada taraf signifikan 5\% dengan $\mathrm{dk}(20+20-2)=38$ diperoleh $\mathrm{t}_{\text {tabel }}=2,021$.

Dengan demikian, nilai $t_{\text {hitung }}>t_{\text {tabel }}$ yakni $6,80>2,021$, sehingga $\mathrm{H}_{0}$ yang menyatakan tidak terdapat pengaruh yang signifikan terhadap kemampuan empati kelompok B yang dibelajarkan melalui bercerita menggunakan media e-big book dengan kelompok anak yang dibelajarkan melalui pembelajaran konvensional atau pembelajaran biasa pada anak kelompok B TK Inklusi Garuda Billingual School ditolak.

\section{PEMBAHASAN}

Berdasarkan hasil tersebut, kedua kelompok sampel penelitian memiliki kemampuan yang setara, setelah diberikan perlakuan yang berupa pembelajaran bercerita menggunakan media e-bigbook dan mengikuti pembelajaran konvensional diperoleh hasil dari kemampuan empati anak berbeda. Rata-rata, anak yang mengikuti pembelajaran bercerita 
menggunakan media e-bigbook lebih tinggi dibandingkan dengan anak yang mengikuti pembelajaran konvensional.

Berbeda dengan kelompok kontrol, kegiatan pembelajaran konvensional yaitu pembelajaran pada umumnya dan bersifat monoton, dalam hal ini guru lebih aktif daripada anak sehingga peran anak hanyalah menerima, menyimpan dan melakukan segala aktivitas sesuai arahan yang diberikan oleh guru. Pembelajaran yang kurang inovatif dan pemanfaatan media pembelajaran yang kurang baik akan membuat anak mudah bosan. Pembelajaran menggunakan metode bercerita menggunakan media e-bigbook dapat meningkatkan kemampuan empati memberikan anak pengetahuan dan pembelajaran yang menyenangkan. Dengan tampilan media e-bigbook yang cukup besar, sehingga mempermudah anak untuk melihat dan memahami isi dari cerita yang disampaikan melalui media e-bigbook tersebut. Dengan begitu anak dapat melihat langsung bagaimana sikap kepada teman yang berkebutuhan khusus tanpa harus menerka-nerka isi cerita yang biasanya hanya diceritakan dengan cara berceramah oleh guru. Sehingga dapat meningkatkan kemampuan empati pada anak.

Hasil temuan dan penelitian ini memiliki persamaan oleh (Tarini et al., 2018) bahwa pembelajaran menggunakan metode bercerita dapat meningkatkan kemampuan empati anak. Pada hasil penelitian tersebut, kemampuan empati anak mengalami peningkatan yang signifikan dengan metode bercerita. Namun, pada penelitian tersebut media yang digunakan masih berupa buku cerita yang bersifat monoton sehingga anak mudah mengalami kebosanan dalm interaksi pembelajran. Pada penelitian ini, metode bercerita menggunakan media yang sudah diinovasi yaitu menggunakan media $e$-bigbook. Media $e$ bigbook merupakan suatu inovasi media pembelajaran yang dapat mendorong minat dan rasa ingin tahu pada anak. Kegiatan pembelajaran menggunakan media e-bigbook dalam penelitian ini membawa dampak yang positif bagi anak dan memberikan efek yang menyenangkan yang dirasakan anak. Media e-bigbook tergolong cukup baru dan merupakan solusi dalam pembelajaran yang bersifat konvensional. Dalam penggunaan ebigbook, anak memunculkan kepuasan karena menggunakan layar proyektor yang memiliki ukuran besar. Tampilan yang cukup besar memudahkan anak dalam melihat media, sembari dalam mendengarkan guru yang tengah bercerita anak juga mulai berinteraksi dengan menunjuk kearah tampilan layar pada objek-objek tertentu. Guru merespon positif dan anak lebih termotivasi dalam mendengarkan isi cerita, sehingga guru dapat menyelipkan pesan moral dari isi cerita yang dapat meningkatkan kemampuan empati anak.

Dengan demikian, hasil dari penelitian menunjukkan bahwa pembelajaran bercerita menggunakan media e-bigbook pada penelitian ini memiliki keunggulan yaitu dapat meningkatkan kemampuan empati anak, dapat meningkatkan rasa saling mengerti anak, dapat meningkatkan kemampuan merasakan yang orang lain rasakan pada anak dan dapat menerapkannya, melalui serangkaian usaha anak dengan lingkungan belajar dan kehidupan sehari-hari anak yang didukung oleh peranan guru dalam pemberian pembelajaran. Kemudian dengan kelebihan dari media e-bigbook guru dapat menambahkan inovasi dalam memperbarui gaya belajar dengan media yang lebih menarik bagi anak.

\section{SIMPULAN}

Adapun yang dapat disimpulkan melalui bercerita menggunakan media e-bigbook kemampuan empati anak kelompok B TK Inklusi Garuda Billingual School Tahun Ajaran 
2019/2020 adalah sebagai berikut. Pembelajaran bercerita menggunakan media e-bigbook dalam penelitian ini memiliki keunggulan yang dapat meningkatkan kemampuan empati anak, dapat meningkatkan rasa saling menghargai dan dapat meningkatkan sikap toleransi pada anak. Melalui lingkungan belajar anak, anak akan lebih mudah menerima pemberian pelajaran yang disampaikan oleh guru. Berdasarkan temuan yang diperoleh, Adapun saran yang terdapat pada penelitian ini yaitu, guru lebih berinovasi dalam mengembangkan media pembelajaran dan penelitian ini dapat dijadikan acuan untuk merancang pembelajaran yang menyenangkan bagi anak dengan tujuan memperoleh hasil belajar yang optimal. Fasilitas berupa media pembelajaran bagi anak akan memberi kesempatan yang lebih besar kepada anak untuk menjadikan pembelajaran suatu proses yang menyenangkan.

\section{DAFTAR PUSTAKA}

Agung, G. (2014). Metodologi Penelitian Pendididkan. Aditya Media Publishing.

Ambarani, P. K. W., Pudjawan, K., \& Tirtayani, L. A. (2015). Penerapan metode bercerita berbantuan media gambar berseri untuk meningkatkan keterampilan menyimak anak. E-Journal PG PAUD Universitas Pendidikan Ganesha, 3(1). https://doi.org/http://dx.doi.org/10.23887/paud.v3i1.5906

Anggraeni, D., Hartati, S., \& Nurani, Y. (2019). Implementasi metode bercerita dan harga diri dalam meningkatkan kemampuan berbicara anak usia dini. Jurnal Obsesi : Jurnal Pendidikan Anak Usia Dini, 3(2), 404. https://doi.org/10.31004/obsesi.v3i2.224

Dewi, K. M. P., Tirtayani, L. A., \& Sujana, I. W. (2018). Pengaruh metode sosiodrama terhadap kemampuan komunikasi verbal anak dengan tunagrahita di paud Dharma Wangsa Denpasar Barat. E-Journal PG PAUD Universitas Pendidikan Ganesha, 6(1). https://ejournal.undiksha.ac.id/index.php/JJPAUD/article/download/15084/12977

Dewi, N. P. D. S., Tirtayani, L. A., \& Ganing, N. N. (2019). Pengaruh metode bercerita terhadap kemampuan empati anak kelompok B. Jurnal Pendidikan Anak Usia Dini Undiksha, 7(1), 78-87. https://doi.org/10.23887/paud.v7i1.18761

Faizah, F., Kurniawati, Y., \& Rahma, U. (2017). Empati terhadap siswa berkebutuhan khusus: ditinjau dari jenjang pendidikan inklusi dan jenis kelamin. Jurnal Psikologi Undip, 16(1), 1. https://doi.org/10.14710/jpu.16.1.1-7

Fauziddin, M., \& Mufarizuddin, M. (2018). Useful of clap hand games for optimalize cogtivite aspects in early childhood education. Jurnal Obsesi : Jurnal Pendidikan Anak Usia Dini, 2(2), 162. https://doi.org/10.31004/obsesi.v2i2.76

Fudyartanta, K. (2016). Psikologi Umum. Pustaka Pelajar.

Hasanah, U., \& Nurhamida, Y. (2016). Sikap siswa reguler terhadap siswa berkebutuhan khusus dengan kecenderungan bullyinng kelas inklusi. Jurnal Psikologi Islam AlQalb, 7(1). https://doi.org/https://doi.org/10.15548/alqalb.v7i1.837

Heldanita, H. (2018). Konsep pendidikan inklusif pada lembaga pendidikan anak usia dini. Golden Age: Jurnal Ilmiah Tumbuh Kembang Anak Usia Dini, 1(3), 16-24. https://doi.org/10.14421/jga.2016.\%x

Juita, R. (2012). Peningkatan kemampuan berhitung anak melalui permainan menakar air di TK Aisyiyah Koto Kaciak Maninjau. Jurnal Ilmiah Pesona Paud, 1(3). https://doi.org/10.16309/j.cnki.issn.1007-1776.2003.03.004

Khairi, H. (2018). Karakterisik perkembangan anak usia dini dari 0-6 tahun. Jurnal Warna, 
$2(2 \quad$ Desember),

$15-28$.

https://ejournal.iaiig.ac.id/index.php/warna/article/viewFile/87/91

Listika, L. I., \& Wati, A. R. (2018). Perbedaan empati siswa normal terhadap anak berkebutuhan khusus ditinjau dari jenis sekolah (inklusi dan reguler). Psikologi Perkembangan, 9(1). https://doi.org/https://doi.org/10.21107/personifikasi.v9i1.6759

Masdudi, M. (2015). Karakteristik Perkembangan Pendidikan Anak Usia Dini. AWLADY: Jurnal Pendidikan Anak, 1(2), 1-26. https://doi.org/10.24235/awlady.v1i2.739

Paramita, N. M. M., Tirtayani, L. A., \& Asri, I. G. A. A. S. (2018). Pengaruh metode bercerita lokal Bali terhadap nilai karakter anak kelompok B TK gugus melati kecamatan Marga. E-Journal PG PAUD Universitas Pendidikan Ganesha, 6(3), 363372.

https://ejournal.undiksha.ac.id/index.php/JJPAUD/article/download/15242/9304

Pratama, W., \& Simaremare, A. (2016). Pengaruh metode bercerita terhadap pengembangan sikap empati anak usia 5-6 tahun di TK / RA Binmudora Tanjung $\begin{array}{lllllll}\text { Morawa } T & \text {. A } 2015 \quad / & 2016 . & 2(2), & 42-48 .\end{array}$ https://jurnal.unimed.ac.id/2012/index.php/jhp/article/view/9424

Prihanjani, N. L., Wirya, I. N., \& Tirtayani, L. A. (2016). Penerapan metode bercerita berbantuan media boneka tangan untuk meningkatkan kemampuan berbicara anak usia 5-6. E-Journal PG PAUD Universitas Pendidikan Ganesha, 4(3). https://ejournal.undiksha.ac.id/index.php/JJPAUD/article/download/8822/5709

Putri, H. (2017). Penggunaan metode cerita untuk mengembangkan nilai moral anak TK/SD. Jurnal Madrasah Ibtidaiyah, 3(1). https://media.neliti.com/media/publications/222482-penggunaan-metode-ceritauntuk-mengemban.pdf

Rahmawati, I. (2019). Pengaruh Media Big Book Terhadap Perkembangan Kemampuan Membaca Awal Pada Anak Kelompok B Di Taman Kanak-Kanak (TK) Namira School Kraksaan Probolinggo.

Safitri, N. K. D. A., Tirtayani, L. A., \& Putra, D. K. N. S. P. (2018). Pengaruh cerita pendek berbasis kearifan lokal terhadap kemampuan empati anak kelompok B paud gugus anggrek. E-Journal PG PAUD Universitas Pendidikan Ganesha, 6(1). https://ejournal.undiksha.ac.id/index.php/JJPAUD/article/download/15093/12979

Sakinah, D. N., \& Marlina, M. (2018). Perilaku bullying terhadap anak berkebutuhan khusus di sekolah inklusif kota Padang. Jurnal Penelitian Pendidikan Khusus, 6(2), 1-6. http://ejournal.unp.ac.id/index.php/jupekhu/article/view/101497/100592

Silfiasari, S. P. (2017). Empati Dan Pemaafan Dalam Hubungan Pertemanan Siswa Regular Kepada Siswa Berkebutuhan Khusus (Abk) Di Sekolah Inklusif. Journal of Chemical Information and Modeling, 5(2). https://doi.org/10.1017/CBO9781107415324.004

Sufriani, S., \& Sari, E. P. (2017). Faktor yang mempengaruhi bullying pada anak usia sekolah di sekolah dasar kecamatan Syiah Kuala Banda Aceh. IDEA NURSING JOURNAL, 8(3). http://jurnal.unsyiah.ac.id/INJ/article/view/9678

Sugiyono. (2017). Metode Penelitian Bisnis. In Bandung: Alfabeta. https://doi.org/10.1016/j.maturitas.2005.10.005

Sulaiman, U. (2017). Pengaruh penggunaan media big book dalam pembelajaran terhadap keterampilan literasi siswa kelas awal madrasah ibtidaiyah negeri Banta-Bantaeng Makassar.

Jurnal

Al-Kalam,

$I X(2)$. 
https://ejournal.iaiig.ac.id/index.php/warna/article/viewFile/87/91

Susanto, A. (2015). Bimbingan Dan Konseling Di Taman Kanak Kanak. Prenadamedia Group.

Tarini, N. M. W. S., Putra, I. K. A., \& Tirtayani, L. A. (2018). Pengaruh metode bercerita menggunakan cerita rakyat terhadap perilaku empati anak kelompok B. E-Journal $P G$ PAUD Universitas Pendidikan Ganesha, 6(1), 43-53. https://ejournal.undiksha.ac.id/index.php/JJPAUD/article/view/15044

Widalisma, M., \& Lestari, N. D. (2017). Analisis Hasil Belajar Mahasiswa Menggunakan Media Cetak dengan Media Elektronik Pada Mata Kuliah Matematika Ekonomi di Universitas PGRI Palembang Merlyn. Jurnal PINUS, 3(1), 41-48. https://doi.org/https://doi.org/10.29407/pn.v3i1.972 